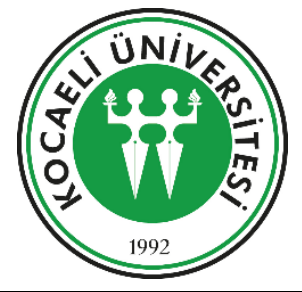

Kocaeli Üniversitesi Sağlık Bilimleri Dergisi

Özgün Araştırma / Original Article

http://dergipark.gov.tr/kusbed

\title{
COMPARISON OF THE EFFICIENCY OF CONVENTIONAL DIFFUSION, DIFFUSION TENSOR IMAGING, AND DYNAMIC SUSCEPTIBILITY CONTRAST-ENHANCED MAGNETIC RESONANCE PERFUSION IMAGING IN THE EVALUATION OF LIVER FIBROSIS
}

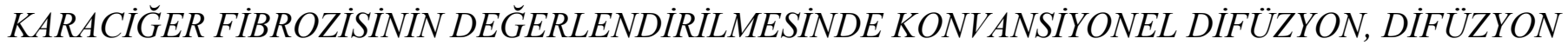 TENSÖR GÖRÜNTÜLEME VE DINAMIK DUYARLILIK KONTRASTLI MANYETIK REZONANS PERFÜZYON GÖRÜNTÜLEMENIN ETKINLIĞININ KARŞILAŞTIRILMASI}

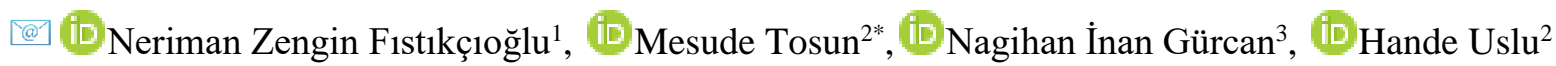

${ }^{1}$ Kartal Lütfi Kirdar, Training and Research Hospital, Department of Radiology, Health Sciences University; Istanbul, Turkey, ${ }^{2}$ Kocaeli University, School of Medicine, Department of Radiology, Kocaeli, Turkey, ${ }^{3}$ Demiroglu Bilim University, Medical School, Department of Radiology, Istanbul, Turkey,

ORCID iD: Mesude Tosun: 0000-0001-8278-108X; Neriman Zengin Fıstıkçığlu: 0000-0003-0088-4160; Nagihan İnan Gürcan: 0000-0003-10486449; Hande Uslu: 0000-0003-1530-2573

*Sorumlu Yazar / Corresponding Author: Mesude Tosun, e-posta / e-mail: mesudetosun @ hotmail.com

Geliş Tarihi / Received: 14.05 .2021

Kabul Tarihi / Accepted: 10.08 .2021

Yayım Tarihi / Published: 31.10 .2021

\begin{abstract}
Objective: Liver fibrosis is a dynamic, reversible process that can result in liver failure. There has been considerable interest in developing noninvasive methods for diagnosis and staging. To investigate the diffusion and perfusion changes of the fibrotic liver parenchyma with conventional diffusion-weighted imaging (CDI), diffusion tensor imaging (DTI), and T2*weighted dynamic susceptibility contrast-magnetic resonance perfusion imaging (DSC-MRPI) at 3Tesla MR scanner.

Methods: Twenty-seven patients with chronic viral hepatitis and 24 volunteers were evaluated, prospectively. The standard MRI protocols of the abdomen, CDI, and DTI were performed. Apparent diffusion coefficient (ADC) maps were obtained, D and FA values were calculated for DTI. Signal Intensity(SI)time curves were obtained and "blood volume"(BV), "blood flow" (BF), "time to peak"(TTP), "mean transit time"(MTT) were measured. All patients with hepatitis underwent liver biopsy. The efficacy of diffusion and perfusion parameters used in the diagnosis of fibrosis was analyzed with the receiver operating characteristic curve (ROC).

Results: Patients had significantly lower liver ADC when compared to the control group, either with CDI and DTI. D values obtained from DTI were lower in patients than those of the normal volunteers, and the difference was statistically significant. On DSC-MRPI; BF, BV, MTT, and TTP of the liver were lower than those of the control group but only BV and MTT values showed statistical significance. Liver ADC, D, and BV values had a negative correlation with fibrosis.

Conclusion: The results showed that the D values obtained from DTI, BV, and MTT values obtained from DSC-MRPI can be an efficient diagnostic tool for liver fibrosis in patients with chronic hepatitis.
\end{abstract}

Keywords: Liver fibrosis, chronic hepatitis, conventional diffusion imaging, diffusion tensor imaging, dynamic susceptibility contrast magnetic resonance perfusion imaging.

$\ddot{O} \mathbf{z}$

Amaç: Karaciğer fibrozu, karaciğer yetmezliğine neden olabilen dinamik, geri dönüşümlü bir süreçtir. Teşhis ve evreleme için noninvaziv yöntemlerin geliştirilmesine büyük ilgi vardır. 3Tesla MR'da konvansiyonel difüzyon ağılıklı görüntüleme (DAG), difüzyon tensör görüntüleme (DTG) ve T2* ağırlıklı dinamik duyarlılık kontrastlı manyetik rezonans perfüzyon görüntüleme (DDK-MRPG) ile fibrotik karaciğer parankiminin difüzyon ve perfüzyon değişikliklerini araştırmayı amaçladık.

Yöntem: Kronik viral hepatiti olan 27 hasta ve 24 gönüllü prospektif olarak değerlendirildi. Rutin batın MR protokolüne ek olarak DAG ve DTG uygulandı. Görünür difüzyon katsayısı (ADC) haritaları elde edildi, DTG için D ve FA değerleri hesaplandı. Sinyal Yoğunluğu (SI)-zaman eğrisi elde edildi ve "kan volümü" (KV), "kan akımı" (KA), "pik zamanı" (PZ), "ortalama geçiş zamanı" (OGZ) ölçüldü. Hepatitli tüm hastalara karaciğer biyopsisi yapıldı. Fibrozis tanısında kullanılan difüzyon ve perfüzyon parametrelerinin etkinliği, ROC eğrisi ile analiz edildi.

Bulgular: Hastalar, DAG ve DTG de kontrol grubuna kıyasla önemli ölçüde daha düşük karaciğer ADC'sine sahipti, DTG'den elde edilen D değerleri hastalarda, sağlıklı gönüllülere göre düşük olup fark istatistiksel olarak anlamlıydı. DDK-MRPG hakkında; Karaciğerin KA, KV, OGZ ve PZ'nı kontrol grubuna göre daha düşüktü ancak sadece KV ve OGZ değerleri istatistiksel anlamlılık gösterdi. Karaciğer ADC, D ve KV değerleri fibrozis ile negatif korelasyona sahipti.

Sonuç: DDK-MRPG'den elde edilen KV ve OGZ, DTG'den elde edilen D değerlerinin kronik hepatitli hastalarda karaciğer fibrozisi için etkili bir tanı aracı olabileceğini gösterdi.

Anahtar Kelimeler: Karaciğer fibrozisi, kronik hepatit, konvansiyonel difüzyon görüntüleme, difüzyon tensör görüntüleme, dinamik duyarlılık kontrast manyetik rezonas perfüzyon görüntüleme. 


\section{Introduction}

Chronic viral hepatitis is a potential cause of morbidity and mortality. ${ }^{1}$ The most important complications of viral hepatitis are liver fibrosis, hepatic decompensation, hepatocellular cancer, and cirrhosis. ${ }^{2,3}$ Early diagnosis and detection of liver fibrosis for effective treatments to halt progression to cirrhosis. ${ }^{4}$ To confirm the diagnosis of hepatic fibrosis and determination of the stage of fibrosis, a biopsy is still required; however, as an invasive procedure, the biopsy is associated with several risks and limitations such as sampling error and interobserver variability. ${ }^{5-7}$ Several imaging modalities have been developed for the diagnosis and staging of liver fibrosis. ${ }^{8,9}$ Conventional diffusion-weighted imaging (CDI) provides a proper assessment of microstructural tissue alterations in the liver parenchyma. Diffusion tensor imaging (DTI) uses at least six diffusion-coding gradients applied in different directions to determine the degree of diffusion. The potential benefit of high magnetic field imaging is the high signal-to-noise ratio (SNR), which provides high temporal and spatial resolution. Dynamic contrast-enhanced (DCE) Magnetic Resonance Imaging (MRI) has been applied for functional information of tissue perfusion and angiogenesis. Liver fibrosis is characterized by increased intrahepatic vascular resistance and a decrease in the exchange between sinusoids and hepatocytes. These changes can be assessed by DCE-MRI; however, the analysis in this modality is complex and has been the basis of many methodological studies, therefore, the clinical use of this modality is rare. ${ }^{10}$

$\mathrm{T} 2 *$-weighted dynamic susceptibility contrast-magnetic resonance perfusion imaging (DSC-MRPI) has been used in neuroimaging. When a bolus of contrast agent passes through the arterial and capillary circulation, it produces local magnetic susceptibility (T2*) effects that induce temporary signal drop. The degree of the signal drop depends on the contrast agent concentration in the blood and blood volume. The transient signal drop graph against time can be used to calculate the hemodynamic blood volume map that reflects the microvascularity (capillary level) of tissue. ${ }^{11}$ There are a few reports of use in the abdominal region, and all of them have been done on a $1 .^{5}$ Tesla MR scanner. ${ }^{11-13}$ However; there has been no report for detecting the perfusion of the liver parenchyma to our knowledge. We report our experience with DSC-MRPI to obtain and reconstruct hepatic $\mathrm{BV}$ maps in patients with chronic hepatitis-induced liver fibrosis.

The first aim of the study was to evaluate and compare the use of apparent diffusion coefficient (ADC) measurements obtained from two different techniques for the assessment of liver fibrosis or fibrosis staging. Second, to investigate the feasibility of DCE-MRPI to assess the degree of liver fibrosis.

\section{Methods}

\section{Patients}

A total of 27 patients diagnosed with chronic hepatitis B based on laboratory tests and liver biopsy results as well as 24 healthy individuals were included in this study from February 2013 to December 2018. This single-center prospective study was approved by the institutional ethics committee. The study was conducted according to the criteria set by the declaration of Helsinki and each subject signed informed consent before participating in the study.

\section{MRI protocol}

All MRI studies were performed on a 3 Tesla (T) MR scanner (Philips Achieva Intera Release, Eindhoven, The Netherlands) with a 16-channel phased-array body torso coil system. Following routine upper abdominal imaging, DWI was obtained using the following parameters; repetition time (TR), $2452 \mathrm{~ms}$; echo time (TE) $67 \mathrm{~ms}$; EPI factor: 57; gradients in the $\mathrm{x}, \mathrm{y}$, and $\mathrm{z}$ directions. Four different $\mathrm{b}$ values (b0, 20, 650, 1000) were used for CDI. DTI (TR: 3000/TE: 57/EPI factor:87;16 directions) was acquired using $\mathrm{b}$ values of 0 and $1000 \mathrm{~s} / \mathrm{mm} 2$. ADC maps $(\mathrm{ADC} 1=\mathrm{b} 0-20, \quad \mathrm{ADC} 2=\mathrm{b} 0-650, \quad \mathrm{ADC} 3=\mathrm{b} 0-1000 \mathrm{~s} / \mathrm{mm} 2)$ were reconstructed automatically from conventional DWI using all $\mathrm{b}$ values. After that, DSC-MRPI with T2*W GREEPI sequence (TR/TE:1564/40, EPI factor:47, FOV:300, SENSE:4, slice thickness:3.5 mm, no gap) were acquired immediately after contrast administration (0-60 sec). Axial 3D-enhanced THRIVE was performed before and after the intravenous injection of Gd-DTPA (Magnevist; Schering). Gd-DTPA $(0.2 \mathrm{~mL} / \mathrm{kg})$ was injected at a rate of $4 \mathrm{~mL} / \mathrm{s}$ via a power injector. After that, $20 \mathrm{~mL}$ of saline flush was administrated at the same injection rate. For perfusion imaging, a one-minute-long breath-hold axial $\mathrm{T} 2 * \mathrm{~W} 20$ section fat suppression GRE-EPI sequence for the upper abdomen was performed with 5 seconds intervals, and perfusion examination consisting of 11 scannings was obtained in 60 seconds.

\section{Histopathological analysis}

All patients underwent ultrasound-guided percutaneous liver biopsy using an 18-gauge spring-loaded biopsy device, after Magnetic resonance (MR) examination. All specimens were evaluated by a histopathologist. Staging and grading of liver histopathology were performed according to the modified Knodell score. ${ }^{14}$ According to Knodell scores, no / mild fibrosis stage was defined as F0-F2, clinically significant fibrosis stage F3-F6. The distribution of patients with hepatitis by fibrosis stage was as follows: stage 1: 5, stage $2: 2$, stage $3: 8$, stage $4: 9$, and stage $5: 3$.

\section{Quantitative image analyses}

All MR image analysis was performed on a workstation with dedicated software (Philips MR workspace, Philips Medical System). The regions of interest with a mean size of 200-250 $\mathrm{mm}^{2}$ were placed on the ADC map at three different regions of hepatic and splenic parenchyma, avoiding the adjacent vascular or biliary structures (Figure 1). Signal intensities (SIs) of the liver parenchyma were measured. The mean of three measurements was recorded as the final ADC. The mean ADCs obtained from CDI, diffusion tensor (D), and fractional anisotropy (FA) values obtained from DTI of liver parenchyma were calculated. Quantitative evaluation of dynamic images, SI-time curve was obtained, and "blood volume" (BV), "blood flow" (BF), "time to peak" (TTP), "mean transit time" (MTT) of two groups were measured.

\section{Statistical Analysis}

Histopathology was accepted as a reference for the statistical analysis. Kolmogorov-Smirnov assessment was used to test the normality of data distribution. Since the numerical data were normally distributed, the differences in the parameters between the patient and the healthy control group were analyzed by the Student t-test. The differences of the ADC values between fibrotic and normal parenchyma were analyzed by Student t-test. The comparison of the 
mean diffusion and perfusion parameters of the patients at different stages was performed with the Mann-Whitney-U test. The Pearson correlation coefficient was used for correlation between diffusion and perfusion parameters and liver fibrotic stage. The efficacy of diffusion and perfusion parameters used in the diagnosis of fibrosis in the differential diagnosis was analyzed with the receiver operating characteristic curve. The threshold values giving the optimal sensitivity and specificity for separation of the patient and control groups were calculated. All statistical analyses were performed using SPSS software ver. 22.0 (IBM, Armonk, NY, USA). The pvalues of less than 0.05 were considered tobe significant.

\section{Results}

\section{Quantitative analysis of MRI}

The results from quantitative analysis of CDI and DTI are provided in Table 1 . All $\mathrm{b}$ values in the liver and spleen in the trace images in the patient group did not show a significant difference compared to the control group. Although liver ADC1, ADC2, and ADC3 values were lower in the patient group compared to the control group, no statistically significant difference was found in all three values. The $\mathrm{D}$ values of the liver were lower in the patient groups compared to the control groups, and the difference was statistically significant $(p=0.022)$. The FA values were also significantly higher than healthy individuals, but there was no statistically significant difference $(p=0.236)$. Liver and spleen perfusion parameters in DSC-MRPI are summarized in table 2. According to this; on DSC-MRPI; $\mathrm{BF}, \mathrm{BV}, \mathrm{MTT}$, and TTP of the liver parenchyma were lower than those of the healthy volunteers, but there was a statistically significant difference between BV and MTT values $(p<0,005)$. There was no statistically significant difference between the patient and control groups in D values measured from spleen parenchyma.

The correlation between the fibrotic stage and the mean diffusion and perfusion values of the liver parenchyma is shown in table 3. According to this, liver ADC, D, and BV values were inversely correlated with fibrosis $(p=0.006$, $p=0.009, \quad p=0.047$, respectively). Pearson correlation analysis showed that lower ADC and $\mathrm{BV}$ values were associated with higher fibrosis scores. Also, there was a negative correlation between the fibrotic stage and the SI values of the splenic parenchyma on trace images b0, b20, b1000 $\mathrm{s} / \mathrm{mm}^{2}$. The mean diffusion and perfusion values of the liver parenchyma according to the fibrosis stages are shown in Table 4. In summary, there was a statistically significant difference between early-stage (stage 1,2) and advanced stage (stage 3,4) ADC1 values.

According to the ROC analysis, the best discriminative parameter was BV obtained from DSC-MRPI. The area under the curve was $0.731 \pm 0.078$. With the cut-off value
$1586.95 \mathrm{~mL} / 100 \mathrm{~g}$ for BV, DSC-MRPI obtained a sensitivity of $\% 72$ and specificity of $\% 70$.

Table 1. The values obtained from CDI and DTI in liver

\begin{tabular}{|c|c|c|c|c|}
\hline & \multicolumn{3}{|c|}{ Liver } \\
\hline & & Patient $(n=27)$ & Control $(n=24)$ & $p$ \\
\hline \multirow{4}{*}{ SIs } & b $0 \mathrm{~s} / \mathbf{m m}^{2}$ & $307.34 \pm 123.54$ & $324.75 \pm 144.06$ & $p=0.647$ \\
\hline & b $20 \mathrm{~s} / \mathrm{mm}^{2}$ & $236.89 \pm 85.72$ & $262.49 \pm 125.60$ & $p=0.406$ \\
\hline & b $650\left(\mathrm{~s} / \mathrm{mm}^{2}\right)$ & $142.30 \pm 64.09$ & $144.82 \pm 78.77$ & $p=0.901$ \\
\hline & b $1000\left(\mathrm{~s} / \mathrm{mm}^{2}\right)$ & $102.43 \pm 40.99$ & $110.42 \pm 60.32$ & $p=0.588$ \\
\hline \multicolumn{2}{|c|}{$\mathrm{ADC}_{1}\left(\mathrm{~mm}^{2} / \mathrm{s}\right)$} & $14.09 \pm 5.94 \times 10^{-3}$ & $15.27 \pm 6.68 \times 10^{-3}$ & $p=0.510$ \\
\hline \multicolumn{2}{|c|}{$\mathrm{ADC}_{2}\left(\mathrm{~mm}^{2} / \mathrm{s}\right)$} & $1.44 \pm 0.38 \times 10^{-3}$ & $1.62 \pm 0.41 \times 10^{-3}$ & $p=0.121$ \\
\hline \multicolumn{2}{|c|}{$\mathrm{ADC}_{3}\left(\mathrm{~mm}^{2} / \mathrm{s}\right)$} & $1.04 \pm 0.32 \times 10^{-3}$ & $1.15 \pm 0.29 \times 10^{-3}$ & $p=0.222$ \\
\hline \multirow{2}{*}{ DTI } & $\mathbf{D}\left(\mathrm{mm}^{2} / \mathbf{s}\right)$ & $1.20 \pm 0.24 \times 10^{-3}$ & $1.41 \pm 0.96 \times 10^{-3}$ & $p=0.027$ \\
\hline & FA & $0.67 \pm 1.05$ & $0.41 \pm 0.13$ & $p=0.236$ \\
\hline
\end{tabular}

CDI: Conventional diffusion-weighted imaging, DTI: Diffusion tensor imaging, SIs: Signal intensity, ADC: Apparent diffusion coefficients, D: Diffusion tensor, FA: Fractional Anisotropy.

Table 2. BF, BV, MTT, and TTP of the liver parenchyma on DSC-MRPI.

\begin{tabular}{l|ccc}
\hline \multicolumn{3}{c}{ Patient } & Civer \\
\hline BF(mL/100g/min) & $104.35 \pm 60.26$ & $126.69 \pm 58.20$ & $p=0.185$ \\
BV(mL/100g) & $1360.62 \pm 1075.12$ & $2460.39 \pm 1873.37$ & $\boldsymbol{p}=\mathbf{0 . 0 1 6}$ \\
TTP(s) & $37.90 \pm 11.386$ & $39.19 \pm 8.361$ & $p=0.643$ \\
MTT(s) & $12.06 \pm 6.798$ & $18.56 \pm 12.693$ & $\boldsymbol{p}=\mathbf{0 . 0 3 2}$ \\
\hline
\end{tabular}

BF: Blood flow $(\mathrm{mL} / 100 \mathrm{~g} / \mathrm{min}), \mathbf{B V}$ : Blood volume $(\mathrm{mL} / 100 \mathrm{~g})$, TTP: Time to peak (s), MTT: Mean transit time (s)

Table 3.The correlation analysis between CDI, DTI, DSC-MRPI parameters and fibrotic stage of liver

\begin{tabular}{|c|c|c|c|}
\hline & \multicolumn{2}{|l|}{ Liver } \\
\hline & & Correlation coefficient (r) & $p$ \\
\hline & $\begin{array}{ll}\text { b 0 } & \left(\mathrm{s} / \mathbf{m m}^{2}\right)\end{array}$ & -0.580 & 0.003 \\
\hline & b $20\left(\mathrm{~s} / \mathrm{mm}^{2}\right)$ & -0.363 & 0.081 \\
\hline SIs & b $650\left(\mathrm{~s} / \mathrm{mm}^{2}\right)$ & -0.031 & 0.885 \\
\hline & b $1000\left(\mathrm{~s} / \mathrm{mm}^{2}\right)$ & -0.204 & 0.339 \\
\hline $\mathbf{A D}$ & $1\left(\mathrm{~mm}^{2} / \mathrm{s}\right)$ & -0.549 & 0.006 \\
\hline $\mathbf{A D}$ & $2\left(\mathrm{~mm}^{2} / \mathrm{s}\right)$ & -0.025 & 0.908 \\
\hline $\mathbf{A D}$ & $3\left(\mathrm{~mm}^{2} / \mathrm{s}\right)$ & -0.248 & 0.243 \\
\hline D (r & $\left.\mathrm{m}^{2} / \mathrm{s}\right)$ & -0.524 & 0.009 \\
\hline FA & & 0.352 & 0.92 \\
\hline BF( & (L/100g/min) & -0.360 & 0.084 \\
\hline BV & nL/100g) & -0.409 & 0.047 \\
\hline TTI & $(\mathrm{sec})$ & -0.207 & 0.202 \\
\hline MT & (sec) & 0.150 & 0.483 \\
\hline
\end{tabular}

SIs: Signal intensity, ADC: Apparent diffusion coefficients, FA: Fractional Anisotropy, BF: Blood flow, BV:Blood volume, TTP: Time to peak, MTT: Mean transit time 


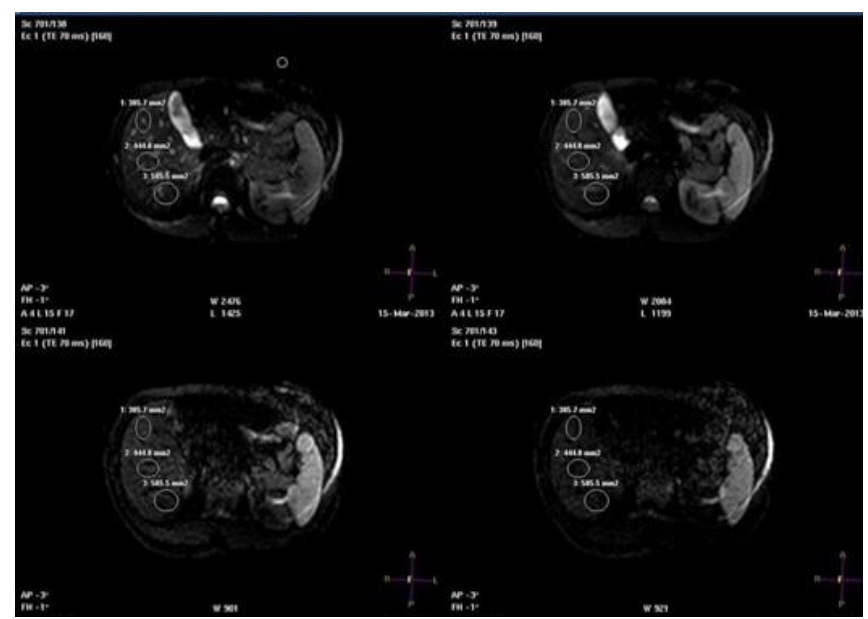

Figure 1. 75-year-old female with stage 2, grade 5 chronic viral hepatitis. Diffusion trace images $\left(b=0, b=20, b=650, b=1000 \mathrm{~s} / \mathrm{mm}^{2}\right)$ show the measured SI in the liver.

Table 4. CDI, DTI, and DSC-MRPG parameters according to liver stages

\begin{tabular}{|c|c|c|c|c|c|}
\hline & Stage 1 & Stage 2 & Stage 3 & Stage 4 & Stage 5 \\
\hline $\mathrm{ADC}_{1}$ & $20.20 \pm 20.08 \times 10^{-3}$ & $24.27 \pm 3.25 \times 10^{-3}$ & $14.31 \pm 4.77 \times 10^{-3}$ & $10.07 \pm 5.65 \times 10^{-3}$ & $14.24 \pm 1.90 \times 10^{-3}$ \\
\hline $\mathrm{ADC}_{2}$ & $1.59 \pm 0.11 \times 10^{-3}$ & $1.48 \pm 0.39 \times 10^{-3}$ & $1.32 \pm 0.29 \times 10^{-3}$ & $1.59 \pm 0.45 \times 10^{-3}$ & $1.37 \pm 0.53 \times 10^{-3}$ \\
\hline $\mathrm{ADC}_{3}$ & $1.24 \pm 0.23 \times 10^{-3}$ & $1.26 \pm 0.17 \times 10^{-3}$ & $0.93 \pm 0.41 \times 10^{-3}$ & $1.14 \pm 1.19 \times 10^{-3}$ & $0.81 \pm 0.54 \times 10^{-3}$ \\
\hline D & $1.49 \pm 0.16 \times 10^{-3}$ & $1.24 \pm 0.26 \times 10^{-3}$ & $1.22 \pm 0.07 \times 10^{-3}$ & $1.03 \pm 0.29 \times 10^{-3}$ & $1.12 \pm 0.17 \times 10^{-3}$ \\
\hline FA & $0.36 \pm 0.14$ & $0.40 \pm 0.18$ & $0.32 \pm 0.09$ & $0.47 \pm 0.15$ & $0.49 \pm 0.02$ \\
\hline BF & $188.14 \pm 88.41$ & $87.56 \pm 3.43$ & $115.32 \pm 51.87$ & $80.09 \pm 49.29$ & $124.32 \pm 59.07$ \\
\hline BV & $2537.49 \pm 955,40$ & $917.42 \pm 10.25$ & $1019.08 \pm 1390.05$ & $790.84 \pm 568.51$ & $1265.80 \pm 841.34$ \\
\hline MTT & $14.87 \pm 8.14$ & $10.48 \pm 0.53$ & $14.32 \pm 7.56$ & $9.82 \pm 6.06$ & $9.65 \pm 1.83$ \\
\hline TTT & $36.60 \pm 14.08$ & $27.50 \pm 18.52$ & $36.48 \pm 8.87$ & $39.60 \pm 13.15$ & $37.60 \pm 11.30$ \\
\hline
\end{tabular}

ADC: Apparent diffusion coefficients, FA: Fractional Anisotropy, BF: Blood flow, BV: Blood volume, TTP: Time to peak, MTT: Mean transit time.

\section{Discussion}

In order to evaluate parenchymal lesions, DWI is an important functional technique. A few studies reported that DWI may also be helpful in the evaluation of diffuse liver lesions. ${ }^{15-18}$ Diffusion restriction can be observed in hypercellular tissues and in cases where extracellular space is reduced. The hyperintensity observed on trace CDI reflects the diffusion restriction. In ADC maps, restricted diffusion areas show low ADC values. The effect of T2 on ADC maps is avoided, but the capillary perfusion effect continues in addition to water diffusion. ${ }^{19}$ Therefore, ADC shows both real diffusion and perfusion (pseudo-diffusion). In our study, we used a low b value (ADC1=b0-20 s/mm²) ADC map to demonstrate the decreasing capillary perfusion effect secondary to parenchymal fibrosis, and high $b$ values (b 650, $1000 \mathrm{~s} / \mathrm{mm}^{2}$ ) ADC maps (ADC2=b0-650, $\mathrm{ADC} 3=\mathrm{b} 0-1000$, respectively) to demonstrate true diffusion restriction. All values were lower in the patient group compared to the healthy group. In the correlation analysis, there was a moderate negative correlation between ADC1 value and liver fibrotic stage. In other words, as the stage increased, the value of ADC1 decreased. There was also a statistically significant difference between early-stage (stage 1 and 2), and advanced stage (stage 3 and 4) mean ADC1 values. The results supported the effect of capillary perfusion on ADC at low $b$ values. In other words, the capillary perfusion effect is evident in ADC1 maps obtained from low b values, and differences in ADC1 values are more pronounced as it changes in liver perfusion in chronic parenchymal disease. The differences between early-stage and advanced-stage mean ADC1 values were statistically significant. The results supported the effect of capillary perfusion on $\mathrm{ADC}$ at lower $\mathrm{b}$ values. Capillary perfusion effect is evident in ADC1 maps obtained from low b values and differences in ADC1 values are more pronounced as it changes in liver perfusion in chronic parenchymal disease. In our study, we also performed measurements of spleen parenchyma to investigate diffusion changes in the spleen due to chronic liver disease. However, the ADC values of the patient with hepatitis were not statistically significant compared with those of controls.

DTI has the potential to contribute to better characterize liver fibrosis by providing information on the function and structure of liver tissue through quantitative measurement of water diffusion and diffusion anisotropy. In the study performed by Taouli et al. in $1.5 \mathrm{~T}$ systems, the ADC values obtained from DWI and DTI were lower in the patients compared to the healthy group. The difference between the two techniques was not statistically significant. The difference between fibrotic stages in DWI was superior to DTI ${ }^{20}$ In our study, D values obtained from DTI were lower in the patients compared to the control group. A moderate negative correlation was found between the fibrotic stage and the D value obtained from DTI.

Mostly, signal intensity-time curves obtained from T1A dynamic images which were taken after given IV contrast agent were used in the liver MRI perfusion studies. The first liver perfusion study was carried out by Scharf et al. in 1999 on 1T MR scanner. ${ }^{21}$ In this study, they reported that there was a correlation in patients with partial portal vein occlusion using the thermal diffusion probe as a reference with MR perfusion parameters. Annet et al. reported that arterial perfusion and MTT increased, portal perfusion and 
BF decreased, in the cirrhotic liver, in T1-W MR perfusion studies. ${ }^{22}$ Increasing of MTT was attributed to extracellular collagen accumulation at Disse distance. Hagiwara et al. reported that arterial blood flow fraction and MTT increased in patients with cirrhotic liver disease. ${ }^{23}$ Chen et al. measured signal intensity in the main portal vein, proximal abdominal aorta, and liver parenchyma in their T1A perfusion study. ${ }^{24}$ In the study, dynamic T1A images were obtained within 100 seconds after contrast was given. As a result of the study, it has been reported that arterial perfusion increases and scattered volume decreases in patients with chronic hepatitis. In this report, although MTT was lower in patients with chronic hepatitis, there was no statistically significant difference.

Although the number of T1W DCE-MRI studies after given contrast is quite high in the literature, the number of $\mathrm{T} 2 * \mathrm{~W}$ DSC-MRPI studies is quite limited. The majority of current studies are animal studies. To our knowledge, there are a few liver studies that evaluated the response of hepatocellular cancers to treatment by this sequence. ${ }^{11-13,25}$, 26 The DSC-MRPI method creates a local magnetic susceptibility $\left(\mathrm{T}^{*}\right)$ effect when a bolus amount of contrast agent is rapidly injected intravenously. A transient signal decrease occurs during the first passage of the contrast agent through the capillary bed. The transient signal reduction is proportional to local $\mathrm{BV}$ and local BF. After this phase, it is also called the perfusion phase, the contrast agent distributes rapidly into the extracellular compartment, and the signal intensity rises. Maps generated from the signal drop during the perfusion phase, show only the difference in perfusion. The transient signal drop may be due to the short T2 relaxation time of tissues. The magnitude of the signal reduction is directly proportional to the change in $\mathrm{T} 2$ relaxation time. In our study, we tried to quantitatively analyze vascular changes due to chronic liver disease in the 3T device with DSC-MRPI technique. We evaluated BV, $\mathrm{BF}$, TTP, and MTT parameters in 27 chronic liver patients with $\mathrm{HBV}$ and HCV. In our measurements, BV, BF, TTP, and MTT were decreased compared to the healthy control group, and the decrease in BV and MTT was statistically significant. In chronic liver disease and cirrhosis, the basal membrane of the endothelial cells changes continuously to a basement membrane, along with loss of fenestration in the sinusoidal walls. As a result, it prevents the passage of the contrast agent to the Disse distance. In addition, the flow decreases in the portal vein, which provides $75 \%$ blood flow of the liver, and the flow in the hepatic artery increases, and intrahepatic shunts are formed between the hepatic artery and the portal vein-hepatic vein. The development of hepatic artery flow and shunts, in addition to the inability of the contrast to pass to the Disse distance due to the reduction of the pores, may reduce the contrast MTT. As a result of the reducement of the total portal vein flow decreases in the total volume of whole blood.

Our study has several limitations. First, the number of patients was not homogeneous according to the fibrotic stage. Second, there were inhomogeneous areas in the parenchyma due to sequential artifacts in DSC-MRPI images. A high b-value DWI had low SNR and image distortion. In addition, there were low SNR and image distortion due to a high b-value DWI. Third, In our study, the biopsy is the reference method for evaluating liver fibrosis, but it only provides a cross-sectional interpretation for the entire liver and is responsible for sampling error due to the heterogeneity in fibrosis distribution and interpretation. Further studies with more patients in each fibrosis group are needed for more generalizable conclusions.

\section{Conclusion}

Our results showed that the D values obtained from DTI, and BV and MTT values obtained from DSC-MRPI can be an efficient diagnostic tool for the diagnosis of liver fibrosis. This may have the potential to be a noninvasive alternative to biopsy, although large patient series are needed to determine which group should benefit from the treatment.

\section{Compliance with Ethical Statement}

This study was approved by The Ethics Committee of Kocaeli University, Turkey (Project number; 2012/100). Written informed consent was obtained from all patients.

\section{Author Contributions}

NZF, NİG, MT: Hypothesis; NZF, NİG, MT, HU: Design; NZF, NIG, MT, HU: Data collection; NZF, NIG, MT, HU: Analysis; NZF, NIG, MT: Literature search; NZF, NIG, MT, HU: Manuscript writing. Final approval of the version to be published: NZF, NIG, MT, HU

\section{Declaration of Conflicting Interests}

No conflict of interest was declared by the authors.

\section{Financial Disclosure}

The authors declared that this study has received no financial support.

\section{References}

1. Bozza C, Cinausero M, Iacono D, Puglisi F. Hepatitis B and cancer: A practical guide for the oncologist. Crit Rev Oncol Hematol . 2016;98:137-146.

2. Polasek M, Fuchs BC, Uppal R, et al. Molecular MR imaging of liver fibrosis: a feasibility study using rat and mouse models. J Hepatol. 2012;57:549-555.

3. Peng CY, Chien RN, Liaw YF. Hepatitis B virus-related decompensated liver cirrhosis: Benefits of antiviral therapy. $J$ Hepatol .2012;57:442-450.

4. Pan S, Wang XQ, Guo QY. Quantitative assessment of hepatic fibrosis in chronic hepatitis B and C: T1 mapping on Gd-EOB-DTPA-enhanced liver magnetic resonance imaging. World J Gastroenterol.2018; 24:2024-2035.

5. Yoon JH, Lee JM, Baek JH, et al. Evaluation of Hepatic Fibrosis Using Intravoxel Incoherent Motion in DiffusionWeighted Liver MRI. J Comput Assist Tomogr. 2014;38:110116.

6. Bedossa P, Darg`ere D, Paradis V. Sampling variability of liver fibrosis in chronic hepatitis C. Hepatology. 2003; 38:1449-1457.

7. Sharma S, Khalili K, Nguyen GC. Non-invasive diagnosis of advanced fibrosis and cirrhosis. World J Gastroenterol. 2014;20:16820-16830.

8. Venkatesh SK, Wang G, Lim SG, Wee A. Magnetic resonance elastography for the detection and staging of liver fibrosis in chronic hepatitis B. Eur Radiol. 2014:24;70-78

9. Tosun M, Onal T, Uslu H, Alparslan B, Çetin Akhan S. Intravoxel incoherent motion imaging for diagnosing and staging the liver fibrosis and inflammation. Abdom Radiol.2020:45;15-23 https://doi.org/10.1007/s00261-01902300-Z

10. Liao YS, Lee LW, Yang PH, et al. Assessment of liver cirrhosis for patients with Child's A classification before hepatectomy using dynamic contrast-enhanced MRI. Clin Radiol. 2019;74:407.e11-407.e17.

11. Chan JH, Tsui EY, Luk SH, et al. Detection of hepatic tumor perfusion following transcatheter arterial chemoembolization 
with dynamic susceptibility contrast-enhanced echoplanar imaging. Clin Imaging. 1999;23:190-194.

12. Ichikawa $\mathrm{T}$, Haradome, Hachiya $\mathrm{J}$, Nitatori $\mathrm{T}$, Araki $\mathrm{T}$. Characterization of hepatic lesions by perfusion-weighted MR imaging with echoplanar sequence. AJR, Am J Roentgenol. 1998;170:1029-1034.

13. Tsui EY, Chan JH, Cheung YK, et al. Evaluation of therapeutic effectiveness of transarterial chemoembolization for hepatocellular carcinoma: correlation of dynamic susceptibility contrast-enhanced echoplanar imaging and hepatic angiography. Clin Imaging. 2000;24:210-216.

14. Knodell RG, Ishak KG, Black WC, et al. Formulation and application of a numerical scoring system for assessing histological activity in asymptomatic chronic active hepatitis. Hepatology. 1981;1:431-435.

15. Taouli B, Tolia AJ, Losada M, et al. Diffusion-weighted MRI for quantification of Liver fibrosis: preliminary experience. Am J Roentgenol. 2007;189:799-806.

16. Koinuma M, Ohashi I, Hanafusa K, Shibuya H. Apparent diffusion coefficient measurements with diffusion-weighted magnetic resonance imaging for evaluation of hepatic fibrosis. J Magn Reson Imaging. 2005;22:80-85.

17. Girometti R, Esposito G, Bagatto D, Avellini C, Bazzocchi M, Zuiani C. Is water diffusion isotropic in the cirrhotic liver? a study with diffusion-weighted imaging at 3.0 Tesla. Acad Radiol. 2012;19:55-61.

18. Palmucci S, Cappello G, Attinà G, et al. Diffusion-weighted MRI for the assessment of liver fibrosis: principles and applications. Biomed Res Int. 2015;874201.

19. Thoeny HC, De Keyzer F, Oyen RH, Peeters RR. Diffusionweighted MR imaging of kidneys in healthy volunteers and patients with parenchymal diseases: initial experience. Radiology. 2005;235: 911-917.

20. Taouli B, Chouli M, Martin AJ,Qayyum A, Coakley FV, VilgrainV. Chronic hepatitis: role of diffusion-weighted imaging and diffusion tensor imaging for the diagnosis of liver fibrosis and inflammation. J Magn Reson Imaging. 2008;28:89-95.

21. Scharf J, Zapletal C, Hess T, et al. Assessment of hepatic perfusion in pigs by pharmacokinetic analysis of dynamic MR images.J Magn Reson Imaging.1999;9:568-572.

22. Annet L, Materne R, Danse E, Jamart J, Horsmans Y, Van Beers BE. Hepatic flow parameters measured with MR imaging and Doppler US: correlations with degree of cirrhosis and portal hypertension. Radiology. 2003;229:409-414.

23. Hagiwara M, Rusinek H, Lee VS, et al. Advanced liver fibrosis: diagnosis with 3D whole-liver perfusion MR imaging initial experience. Radiology. 2008;246: 926-934.

24. Chen BB, Hsu CY, Yu CW, et al. Dynamic contrast-enhanced magnetic resonance imaging with Gd-EOB-DTPA for the evaluation of liver fibrosis in chronic hepatitis patients. Eur Radiol.2012;22:171-180.

25. Chen F, De Keyzer F, Ni Y. Cancer models-multiparametric applications of clinical MRI in rodent hepatic tumor model.Methods Mol Biol. 2011;771;489-507.

26. Chen F, Sun X, De Keyzer F, et al. Liver tumor model with implanted rhabdomyosarcoma in rats: MR imaging, microangiography, and histopathologic analysis. Radiology. 2006;239:554-562. 